\title{
School-based nutrition education: features and challenges for success
}

Mojisola D. Kupolati, Una E. MacIntyre and Gerda J. Gericke

Department of Human Nutrition, University of Pretoria, Pretoria, South Africa

\begin{abstract}
Purpose - School-based nutrition education (NE) possesses the capacity to influence learners' nutrition behaviours. This review aimed at critically assessing published articles on school-based NE intervention in order to identify factors hindering or contributing to the success of interventions.
\end{abstract}

Design/methodology/approach - An electronic search of articles was conducted in Medline, PubMed, CINAHL databases, Google and snow-balling. Included in the review were Schoolbased studies with classroom NE with or without nutrition services and studies published between 2000 and 2013. School-based non-intervention studies and interventions that did not include a nutrition teaching component were excluded in the review.

Findings - Thirty nine studies met the inclusion criteria. Features of successful NE interventions included the use of behavioural theories especially the social cognitive theory (SCT) and the involvement of trained teachers in the implementation of interventions. Capacity development for teachers, time constraints, school policies and implementation problems of multicomponent interventions were some of the identified challenges encountered in the studies reviewed.

Originality/value - Trained teachers are invaluable assets in interventions to improve nutrition behaviours of learners. Challenges associated with teacher oriented school-based NE intervention can be overcome by properly designed and implemented interventions based on behavioural theory.

Keywords School-based, Nutrition education, Nutrition behaviours, Learners, Teachers.

Paper type Literature review 


\section{Background}

Nutrition education (NE) is often used as strategy for nutrition intervention to improve nutritional status, health and nutrition knowledge, attitudes and practices (Perez-Rodigo and Aranceta, 2001). It is a viable effort towards reducing malnutrition among school children. Malnutrition poses a serious challenge to the nutritional well-being of children in developing nations, where the main nutritional problems are wasting, stunting, underweight and micronutrient deficiencies (Unicef, 2009; WHO, 2006). Malnutrition is an impediment to mental and psychomotor development in children, to productivity, economic growth and poverty eradication (United Nations, 2005). Underweight, overweight and obesity are risk factors for chronic diseases, which constitute public health concerns globally (FAO, 2005). In the developed countries, overweight and obesity have reached the level of public health concerns while developing countries are experiencing a double burden of underweight and overweight/obesity (De Onis and Borghi, 2010; Stevens et al., 2012). According to De Onis and colleagues' report, the global prevalence of childhood overweight and obesity increased from $4.2 \%$ in 1990 to $6.6 \%$ in 2010, while that of Africa and Asia were $8.5 \%$ and $4.9 \%$ respectively in 2010. The prevalence of adult overweight and obesity in the last decade increased significantly with nearly one in every three adults in the world being overweight and one in every nine adults being obese in 2008 (WHO, 2013). Obesity in children is linked with higher chances of overweight and obesity in adulthood, besides an increased risk of ill health in the children (Lakshma et al., 2010). The global figures of underweight $(6.7 \%)$, overweight (25.7\%) and obesity (8.9\%) suggested that concerted effort from all stakeholders is necessary to reduce the rising trend of diseases as a result of malnutrition.

$\mathrm{NE}$ in the school environment has received considerable attention from researchers and, as an intervention strategy, has witnessed a gradual change from knowledge orientation to behavioural orientation (Contento, 2008). However, research evidence has shown that 
adequate nutrition knowledge and positive attitudes towards nutrition do not necessarily translate to good dietary practices. NE interventions that have a positive impact on behaviours and not just on knowledge and attitudes are most beneficial and are considered effective (Drake et al., 2002).

There is a growing body of research towards NE interventions to improve school children's dietary intake, nutrition knowledge, attitudes and practices (Shariff et al., 2008; Walsh, et al., 2003). Intervention foci are diverse, addressing various factors such as tools and methods of intervention delivery (Blom-Hoffman et al., 2004; Swindle et al., 2007) and encouraging the consumption of health-promoting foods (Blom-Hoffman et al., 2004). Other areas of focus include physical activity in combination with a nutrition component to optimise health (Cason and Logan, 2006) and issues directly relating to attitudes towards nutrition and behaviour change (Walsh et al., 2003). Implementers of interventions in school-based nutrition can determine the success and sustainability of interventions. NE interventions have been implemented through caregivers (Kabahenda et al., 2011); trained para-professionals (Hildebrand et al., 2012); nutrition advisors (community leaders) trained by nutritionists (Walsh et al., 2003), and health teachers and class teachers trained in the use of a nutrition curriculum (Fahlman et al., 2008). Research designs most often used to implement schoolbased NE include randomised control trials, cluster randomised control trials and quasiexperimental designs (Van Cauwenberghe et al., 2010).

The foundation for effective NE effort is based on theory, and proper application of theory enhances the planning, implementation and evaluation of interventions (Holli et al., 2003). Strategies relevant to behavioural focus and change are rooted in theories. The behavioural change approach is generally based on the assumptions that individuals have a great deal of influence over their personal decisions and actions and that these changes can be used to bring about desirable change in nutrition and health outcomes (Contento, 2008). Theories of 
behaviours such as the Social Cognitive Theory (SCT), the Social Marketing Theory, Stages of Change Theory and Health Promotion Model (HPM) are often used to implement schoolbased NE interventions (Fornari, 2006; Steyn et al., 2009).

School-based nutrition education interventions have documented accompanying successes and challenges. Teachers have been shown to participate actively in most interventions, where they were either used to implement interventions or provide support in other ways. Previous studies have emphasised that the teacher's role is crucial to the success of schoolbased NE interventions. Therefore, a revelation of the barriers and facilitators surrounding teachers' roles in NE in schools may provide meaningful insight into how teachers' participation can be better harnessed to benefit NE interventions in schools.

This review aims to:

- Critically assess published articles on school-based NE interventions; with particular attention to teachers' involvement.

- Identify factors hindering or contributing to the success of school-based NE interventions.

\section{Methods}

The review of literature in respect of school-based NE was conducted between May 2012 and December 2013. An electronic search of peer-reviewed articles written in English was conducted in Medline, PubMed and the Cumulative Index to Nursing and Allied Health Literature (CINAHL) databases. In addition, Google search and snow-balling, using the reference lists of selected articles, were conducted. The search terms used were nutrition education OR nutrition intervention AND school OR elementary AND teacher OR educator AND children OR learner OR student AND nutrition behaviour OR attitude OR dietary 


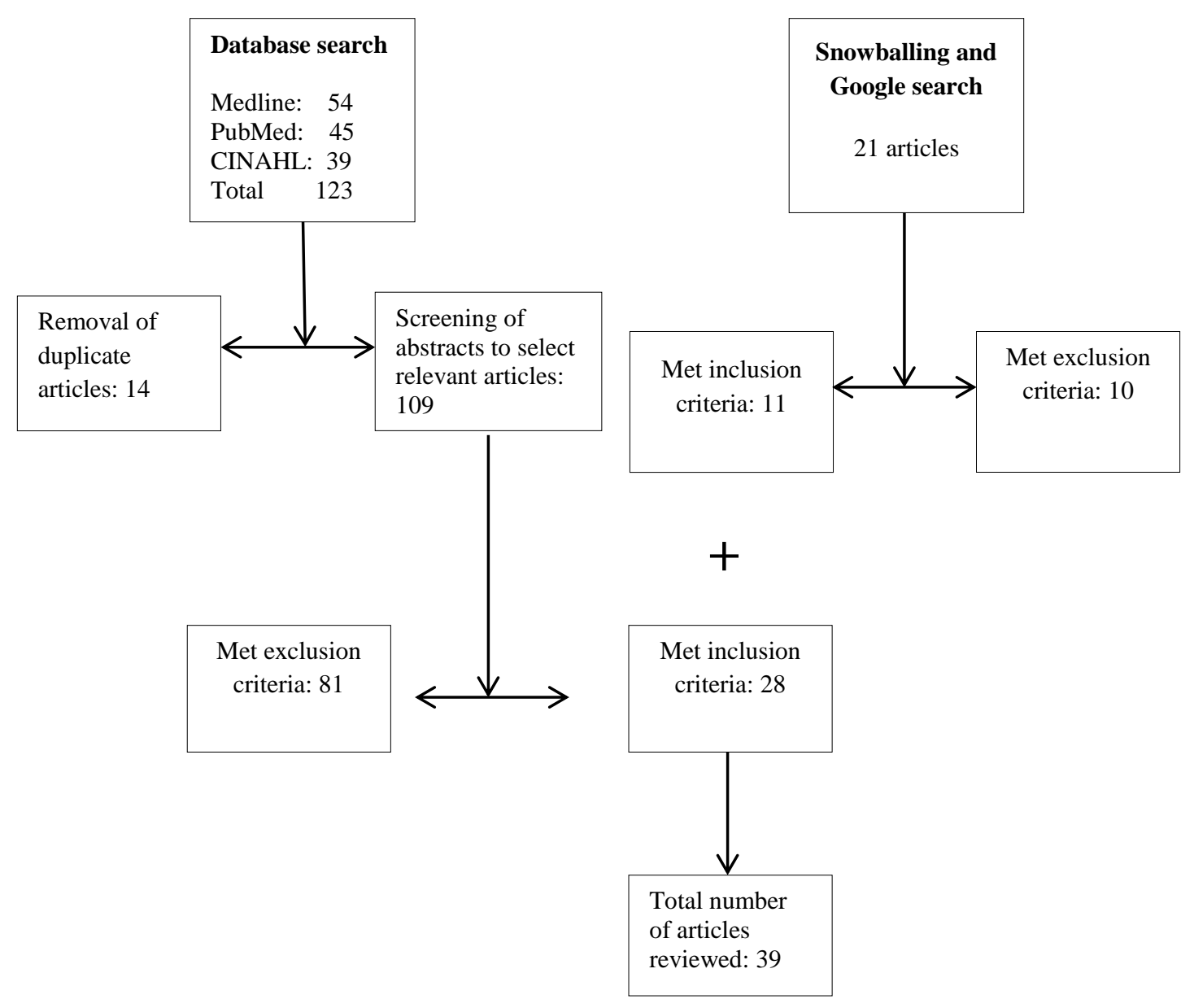

Figure 1 Flow chart illustrating the selection of articles for the review

behaviour. To be eligible for inclusion, studies had to describe NE interventions with or without other nutrition or non-nutrition related services. These services included physical activity (PA), parental involvement, school garden, school policy, school food environment, school meal and health components such as diabetic risks, overweight/obesity and heart health. School based interventions with no nutrition teaching component and nonintervention studies were excluded in the review. The population targeted included 
participants of NE interventions in elementary schools who were learners, teachers, school staff and implementers of interventions. Effectiveness was measured by whether the intervention achieved its desired main objectives. The review is presented under the following headings: general characteristics of articles, features of nutrition education interventions and discussion highlighting facilitators, challenges and implications of research.

\section{Results}

\section{General characteristics of articles}

A total of 123 articles were identified from PubMed, Medline and CINAHL, while 21 additional articles were identified from the Google search and snowballing as shown in figure 1. The articles were screened, using the inclusion and exclusion criteria and 39 articles were selected and reviewed.

School-based NE interventions adjudged to be of best practice and successful were often grounded on a firm theory of behaviours or learning (Contento, 2007). About $10-15$ hour intervention duration was reported necessary to effect knowledge, while 50 hour duration was reported to be required for enduring change in behaviour to occur (Bergen, 1993; Connell, 1985). However variable changes in nutrition behaviours have been reported with duration as low as 5 weeks and up to 5 years (Blom-Hoffman et al., 2004; Hoelscher et al., 2004). In order to provide more evidence and information for this review, articles with a short intervention period and studies that did not involve the use of a theory were included. As a result 2 categories emerged, namely studies which used a minimum of a 3-month intervention period along with at least a theory (table 1), and studies which used varying intervention periods with or without the use of a theory.

Most (19) of the studies reviewed were carried out in the United States of America. The number of study participants varied from a minimum of 33 to a maximum of 7500 learners. Implementations of school-based NE interventions were often scheduled for 1 hour per week. 
Table 1 Summary of articles with 3 months or more intervention duration and the use of theory (in alphabetical order)

\begin{tabular}{|c|c|c|c|c|c|c|c|c|c|}
\hline $\begin{array}{l}\text { Author, year } \\
\text { \& Country }\end{array}$ & $\begin{array}{l}\text { Participant } \\
\text { S }\end{array}$ & $\begin{array}{l}\text { Study } \\
\text { design }\end{array}$ & $\begin{array}{l}\text { Intervention } \\
\text { components }\end{array}$ & $\begin{array}{l}\text { Interv } \\
\text { ention } \\
\text { durati } \\
\text { on }\end{array}$ & Issues addressed & $\begin{array}{l}\text { Theory } \\
\text { based }\end{array}$ & $\begin{array}{l}\text { Intervention } \\
\text { implementer } \\
\mathrm{s}\end{array}$ & Evaluation & Outcomes \\
\hline $\begin{array}{l}\text { Breslin and } \\
\text { Brennan, } 2012 \\
\text { (Northern } \\
\text { Ireland) }\end{array}$ & $\begin{array}{l}416,8-9 \\
\text { year old } \\
\text { children } \\
\text { from } 24 \\
\text { schools }\end{array}$ & $\begin{array}{l}\text { Randomis } \\
\text { ed } \\
\text { controlled } \\
\text { trial }\end{array}$ & $\mathrm{NE}+\mathrm{PA}$ & $\begin{array}{l}12 \\
\text { weeks }\end{array}$ & $\begin{array}{l}\text { To increase PA, } \\
\text { encourage healthy } \\
\text { attitudes and } \\
\text { nutrition } \\
\text { behaviours }\end{array}$ & SCT & $\begin{array}{l}\text { Class teacher } \\
\text { and the } \\
\text { Sports } \\
\text { student } \\
\text { teaching } \\
\text { assistant }\end{array}$ & $\begin{array}{l}\text { Anthropometr } \\
\mathrm{y}, \\
\text { accelerometer } \\
\text { and nutrition } \\
\text { questionnaires } \\
\text { at PPI }\end{array}$ & $\begin{array}{l}\text { Intervention } \\
\text { impacts positively } \\
\text { on children's health } \\
\text { and nutrition } \\
\text { behaviours }\end{array}$ \\
\hline $\begin{array}{l}\text { Burgess- } \\
\text { Champouxt et } \\
\text { al. } 2007 \\
\text { (USA) }\end{array}$ & $\begin{array}{l}150 \text { pairs of } \\
\text { parent/child } \\
\text {. }\end{array}$ & $\begin{array}{l}\text { Quasi } \\
\text { experime } \\
\text { ntal } \\
\text { design }\end{array}$ & $\begin{array}{l}\mathrm{NE}+\text { cafeteria } \\
\text { menu + family } \\
\text { involvement }\end{array}$ & $\begin{array}{l}5 \\
\text { month } \\
\mathrm{s}\end{array}$ & $\begin{array}{l}\text { To increase the } \\
\text { consumption of } \\
\text { whole grains }\end{array}$ & SCT & $\begin{array}{l}\text { Trained } \\
\text { research } \\
\text { assistant }\end{array}$ & $\begin{array}{l}\text { Meal } \\
\text { observation } \\
\text { and survey } \\
\text { questionnaires } \\
\text { at PPI }\end{array}$ & $\begin{array}{l}\text { Increase intake of } \\
\text { whole-grain foods } \\
\text { by learners }\end{array}$ \\
\hline $\begin{array}{l}\text { Draper et al. } \\
2010 \text { (South } \\
\text { Africa) }\end{array}$ & $\begin{array}{l}517 \\
\text { teachers, } \\
8874^{\text {th }} \\
\text { graders }\end{array}$ & $\begin{array}{l}\text { Interventi } \\
\text { on } \\
\text { mapping } \\
\text { approach }\end{array}$ & $\begin{array}{l}\mathrm{NE}+\mathrm{PA}+ \\
\text { Family } \\
\text { involvement + } \\
\text { diabetes } \\
\text { awareness }\end{array}$ & $\begin{array}{l}24 \\
\text { month } \\
\mathrm{s}\end{array}$ & $\begin{array}{l}\text { To increase } \\
\text { healthy eating and } \\
\text { PA so as to } \\
\text { reduce diabetes } \\
\text { risk factors in } \\
\text { children }\end{array}$ & $\begin{array}{l}\text { SEM and } \\
\text { SCT }\end{array}$ & $\begin{array}{l}\text { Trained } \\
\text { educators, } \\
\text { Health-kick } \\
\text { champions } \\
\text { and } \\
\text { educational } \\
\text { psychologists }\end{array}$ & $\begin{array}{l}\text { Anthropometr } \\
\mathrm{y}, \text { nutrition } \\
\text { KAP and PA } \\
\text { questionnaires } \\
\text { at PPI }\end{array}$ & $\begin{array}{l}\text { Educators play key } \\
\text { role in SBI, but } \\
\text { capacity } \\
\text { development is a } \\
\text { challenge }\end{array}$ \\
\hline $\begin{array}{l}\text { Fernandes et } \\
\text { al. } 2009 \\
\text { (Brazil) }\end{array}$ & $\begin{array}{l}1352^{\text {nd }} \\
\text { grade } \\
\text { learners } \\
\text { from } 2 \\
\text { primary } \\
\text { schools }\end{array}$ & $\begin{array}{l}\text { Control } \\
\text { interventi } \\
\text { on trial }\end{array}$ & NE only & $\begin{array}{l}16 \\
\text { weeks }\end{array}$ & $\begin{array}{l}\text { To determine } \\
\text { effect of NE on } \\
\text { overweight/obesit } \\
\text { y and food intake }\end{array}$ & $\begin{array}{l}\text { Learning } \\
\text { through } \\
\text { play }\end{array}$ & $\begin{array}{l}\text { Class } \\
\text { teachers }\end{array}$ & $\begin{array}{l}\text { Anthropometr } \\
\text { y and 3-day } \\
\text { DR at PPI }\end{array}$ & $\begin{array}{l}\text { No significant } \\
\text { changes in BMI but } \\
\text { dietary intake } \\
\text { improved }\end{array}$ \\
\hline
\end{tabular}




\begin{tabular}{|c|c|c|c|c|c|c|c|c|c|}
\hline $\begin{array}{l}\text { Author, year } \\
\text { \& Country }\end{array}$ & $\begin{array}{l}\text { Participant } \\
\text { s }\end{array}$ & $\begin{array}{l}\text { Study } \\
\text { design }\end{array}$ & $\begin{array}{l}\text { Intervention } \\
\text { components }\end{array}$ & $\begin{array}{l}\text { Interv } \\
\text { ention } \\
\text { durati } \\
\text { on }\end{array}$ & Issues addressed & $\begin{array}{l}\text { Theory } \\
\text { based }\end{array}$ & $\begin{array}{l}\text { Intervention } \\
\text { implementer } \\
\mathrm{S}\end{array}$ & Evaluation & Outcomes \\
\hline $\begin{array}{l}\text { Francis et al. } \\
2010 \\
\text { (Trinidad and } \\
\text { Tobago) }\end{array}$ & $\begin{array}{l}5796^{\text {th }} \\
\text { grade } \\
\text { learners } \\
\text { from } 10 \\
\text { schools }\end{array}$ & $\begin{array}{l}\text { Randomis } \\
\text { ed } \\
\text { controlled } \\
\text { trial }\end{array}$ & $\mathrm{NE}+\mathrm{PA}$ & $\begin{array}{l}9 \\
\text { month } \\
\mathrm{s}\end{array}$ & $\begin{array}{l}\text { To improve } \\
\text { nutrition } \\
\text { knowledge } \\
\text { attitudes and } \\
\text { behaviours }\end{array}$ & $\begin{array}{l}\text { Blooms } \\
\text { mastery } \\
\text { learning } \\
\text { model }\end{array}$ & $\begin{array}{l}\text { Trained } \\
\text { teachers }\end{array}$ & $\begin{array}{l}\text { Anthropometr } \\
\mathrm{y}, \\
\text { questionnaires } \\
\text { at PPI and } \\
\text { after 3mths }\end{array}$ & $\begin{array}{l}\text { Improvement in } \\
\text { nutrition } \\
\text { knowledge and } \\
\text { reduced intake of } \\
\text { fried foods }\end{array}$ \\
\hline $\begin{array}{l}\text { Gibbs et al. } \\
2013 \\
\text { (Australia) }\end{array}$ & $\begin{array}{l}764 \\
\text { students and } \\
562 \text { parents }\end{array}$ & $\begin{array}{l}\text { Non- } \\
\text { randomis } \\
\text { ed } \\
\text { comparati } \\
\text { ve study }\end{array}$ & $\begin{array}{l}\text { NE in kitchen } \\
\text { and garden } \\
\text { class }\end{array}$ & 1year & $\begin{array}{l}\text { To increase } \\
\text { children's } \\
\text { appreciation of } \\
\text { diverse and } \\
\text { healthy foods }\end{array}$ & $\begin{array}{l}\text { Social- } \\
\text { ecological } \\
\text { model } \\
\text { and HPM }\end{array}$ & $\begin{array}{l}\text { Teachers, and } \\
\text { kitchen and } \\
\text { garden } \\
\text { specialist } \\
\text { staff }\end{array}$ & $\begin{array}{l}\text { 24-hr DR and } \\
\text { lunchroom } \\
\text { observation at } \\
\text { PPI and over } \\
21 / 2 \text { years }\end{array}$ & $\begin{array}{l}\text { Improved } \\
\text { willingness to try } \\
\text { new foods and } \\
\text { capacity to describe } \\
\text { healthy foods }\end{array}$ \\
\hline $\begin{array}{l}\text { He et al. } 2009 \\
\text { (USA) }\end{array}$ & $\begin{array}{l}12775^{\text {th }} \text { and } \\
8^{\text {th }} \text { grade } \\
\text { learners in } \\
26 \\
\text { elementary } \\
\text { schools }\end{array}$ & $\begin{array}{l}\text { Cluster } \\
\text { randomis } \\
\text { ed } \\
\text { controlled } \\
\text { trial }\end{array}$ & $\begin{array}{l}\text { Enhanced NE } \\
+ \text { FFVS }\end{array}$ & $\begin{array}{l}21 \\
\text { weeks }\end{array}$ & $\begin{array}{l}\text { To assess } \\
\text { psychosocial } \\
\text { variables of } \mathrm{F} \& \mathrm{~V} \\
\text { intake and pattern }\end{array}$ & SCT & $\begin{array}{l}\text { Teachers and } \\
\text { researchers }\end{array}$ & $\begin{array}{l}\text { 24-hr DR, } \\
\text { psychosocial } \\
\text { and food } \\
\text { behavioural } \\
\text { scale at PPI }\end{array}$ & $\begin{array}{l}\text { Improvement in } \\
\text { F\&V intake and } \\
\text { preferences for } \\
\text { certain fruits }\end{array}$ \\
\hline $\begin{array}{l}\text { Jansen } \text { et al. } \\
2008 \\
\text { (Netherlands) }\end{array}$ & $\begin{array}{l}20 \text { primary } \\
\text { schools }\end{array}$ & $\begin{array}{l}\text { Randomis } \\
\text { ed } \\
\text { controlled } \\
\text { trial }\end{array}$ & $\begin{array}{l}\mathrm{NE}+\text { Fitness } \\
\text { testing + PA + } \\
\text { parental } \\
\text { involvement }\end{array}$ & $\begin{array}{l}24 \\
\text { month } \\
\mathrm{s}\end{array}$ & $\begin{array}{l}\text { To reduce } \\
\text { overweight and } \\
\text { inactivity in } \\
\text { children }\end{array}$ & $\begin{array}{l}\text { PB } \\
\text { and EM }\end{array}$ & $\begin{array}{l}\text { Professional } \\
\text { PE teacher } \\
\text { and class } \\
\text { teachers }\end{array}$ & $\begin{array}{l}\text { Anthropometr } \\
\mathrm{y}, \\
\text { questionnaires } \\
\text { at PPI }\end{array}$ & Not reported \\
\hline $\begin{array}{l}\text { Kafatos, et al. } \\
2004(\mathrm{UK})\end{array}$ & $\begin{array}{l}1075^{\text {th }} \\
\text { grade } \\
\text { learners in } 3 \\
\text { primary } \\
\text { schools }\end{array}$ & $\begin{array}{l}\text { Not } \\
\text { specified }\end{array}$ & $\begin{array}{l}\mathrm{NE}+\text { food } \\
\text { advertising }+ \\
\text { label reading }\end{array}$ & $\begin{array}{l}5 \\
\text { month } \\
\mathrm{s}\end{array}$ & $\begin{array}{l}\text { To identify best } \\
\text { teaching practice } \\
\text { in NE } \\
\text { implementation }\end{array}$ & $\begin{array}{l}\text { Participat } \\
\text { ory } \\
\text { observatio } \\
\mathrm{n}\end{array}$ & $\begin{array}{l}\text { Trained } \\
\text { teachers }\end{array}$ & $\begin{array}{l}\text { Nutrition } \\
\text { knowledge } \\
\text { questionnaire } \\
\text { at PPI }\end{array}$ & $\begin{array}{l}\text { Evaluation of } \\
\text { teaching methods } \\
\text { reflected on } \\
\text { learners nutrition } \\
\text { knowledge }\end{array}$ \\
\hline
\end{tabular}




\begin{tabular}{|c|c|c|c|c|c|c|c|c|c|}
\hline $\begin{array}{l}\text { Author, year } \\
\text { \& Country }\end{array}$ & $\begin{array}{l}\text { Participant } \\
\text { s }\end{array}$ & $\begin{array}{l}\text { Study } \\
\text { design }\end{array}$ & $\begin{array}{l}\text { Intervention } \\
\text { components }\end{array}$ & $\begin{array}{l}\text { Interv } \\
\text { ention } \\
\text { durati } \\
\text { on }\end{array}$ & Issues addressed & $\begin{array}{l}\text { Theory } \\
\text { based }\end{array}$ & $\begin{array}{l}\text { Intervention } \\
\text { implementer } \\
\mathrm{S}\end{array}$ & Evaluation & Outcomes \\
\hline $\begin{array}{l}\text { Katz et al. } \\
2011 \text { (USA) }\end{array}$ & $\begin{array}{l}11802^{\text {nd, }} 3^{\text {rd }} \\
\text { and } 4^{\text {th }} \\
\text { grade } \\
\text { learners in } 3 \\
\text { schools }\end{array}$ & $\begin{array}{l}\text { Randomis } \\
\text { ed } \\
\text { controlled } \\
\text { trial }\end{array}$ & $\begin{array}{l}\mathrm{NE}+\text { parental } \\
\text { involvement }\end{array}$ & $\begin{array}{l}4 \\
\text { month } \\
\text { s }\end{array}$ & $\begin{array}{l}\text { To improve } \\
\text { children's' ability } \\
\text { to identify } \\
\text { healthful and less } \\
\text { healthful foods }\end{array}$ & SEM & $\begin{array}{l}\text { Physical } \\
\text { education } \\
\text { instructors }\end{array}$ & $\begin{array}{l}\text { Anthropometr } \\
\mathrm{y}, \text { FFQ and } \\
\text { nutrition } \\
\text { knowledge } \\
\text { questionnaires }\end{array}$ & $\begin{array}{l}\text { Improvement in } \\
\text { ability to identify } \\
\text { more healthful } \\
\text { foods from labels }\end{array}$ \\
\hline $\begin{array}{l}\text { Lee et al. } \\
2013 \text { (USA) }\end{array}$ & $\begin{array}{l}562 \\
\text { students and } \\
8 \text { teachers } \\
\text { in } 5 \text { schools }\end{array}$ & $\begin{array}{l}\text { Convenie } \\
\text { nce and } \\
\text { random } \\
\text { assignme } \\
\text { nt }\end{array}$ & NE only & $\begin{array}{l}10 \\
\text { weeks }\end{array}$ & $\begin{array}{l}\text { To encourage } \\
\text { reduction of } \\
\text { obesity risk } \\
\text { behaviours }\end{array}$ & $\begin{array}{l}\text { SCT and } \\
\text { Self- } \\
\text { determina } \\
\text { tion } \\
\text { theory }\end{array}$ & $\begin{array}{l}\text { Trained } \\
\text { teachers }\end{array}$ & $\begin{array}{l}\text { Quantitative } \\
\text { and } \\
\text { qualitative } \\
\text { survey during } \\
\text { intervention } \\
\text { and at PPI. } \\
\end{array}$ & $\begin{array}{l}\text { Educators } \\
\text { improved } \\
\text { understanding and } \\
\text { implemented } \\
\text { curriculum with } \\
\text { success }\end{array}$ \\
\hline $\begin{array}{l}\text { Lien et al. } \\
2010 \\
\text { (Norway) }\end{array}$ & 114 learners & $\begin{array}{l}\text { Cluster } \\
\text { randomis } \\
\text { ed } \\
\text { controlled } \\
\text { trial }\end{array}$ & $\begin{array}{l}\mathrm{NE}+\mathrm{PA}+ \\
\text { Campaigns }\end{array}$ & $\begin{array}{l}20 \\
\text { month } \\
\mathrm{s}\end{array}$ & $\begin{array}{l}\text { To increase PA, } \\
\text { intake of } F \& V \\
\text { and reduce intake } \\
\text { of sweetened } \\
\text { beverages }\end{array}$ & $\begin{array}{l}\text { SCT and } \\
\text { SEM }\end{array}$ & $\begin{array}{l}\text { Trained } \\
\text { teachers and } \\
\text { researchers }\end{array}$ & $\begin{array}{l}\text { Anthropometr } \\
\text { ic, } \\
\text { Questionnaire } \\
\text { s at PPI }\end{array}$ & $\begin{array}{l}\text { No significant } \\
\text { difference in BMI } \\
\text { between } \\
\text { intervention and } \\
\text { control }\end{array}$ \\
\hline $\begin{array}{l}\text { Prelip, et al. } \\
2012 \text { (USA) }\end{array}$ & $\begin{array}{l}3993^{\text {rd }} 4^{\text {th }} \\
\text { and } 5^{\text {th }} \\
\text { graders, } 56 \\
\text { teachers and } \\
53 \\
\text { mothers }\end{array}$ & $\begin{array}{l}\text { quasi- } \\
\text { experime } \\
\text { ntal } \\
\text { design }\end{array}$ & $\begin{array}{l}\mathrm{NE}+\text { Nutrition } \\
\text { activities }+ \\
\text { parental } \\
\text { involvement }\end{array}$ & $\begin{array}{l}10 \\
\text { month } \\
\mathrm{s}\end{array}$ & $\begin{array}{l}\text { Impact of a } \\
\text { multicomponent } \\
\text { nutrition } \\
\text { education } \\
\text { program on } \\
\text { learners' } \\
\text { F\&V intake }\end{array}$ & $\begin{array}{l}\text { SCT and } \\
\text { Theory of } \\
\text { planned } \\
\text { behaviour }\end{array}$ & $\begin{array}{l}\text { Class } \\
\text { teachers and } \\
\text { research team } \\
\text { members }\end{array}$ & $\begin{array}{l}\text { F\&V KAP } \\
\text { questionnaires } \\
\text { at PPI }\end{array}$ & $\begin{array}{l}\text { No significant } \\
\text { increase in } \\
\text { students' F\&V } \\
\text { intake was } \\
\text { observed }\end{array}$ \\
\hline $\begin{array}{l}\text { Rosario et al. } \\
2012 \\
\text { (Portugal) }\end{array}$ & $\begin{array}{l}464 \\
\text { children, } \\
15 \text { teachers. }\end{array}$ & $\begin{array}{l}\text { Randomis } \\
\text { ed trial }\end{array}$ & $\begin{array}{l}\mathrm{NE}+\text { sessions } \\
\text { of PA }\end{array}$ & $\begin{array}{l}6 \\
\text { month } \\
\text { s- } 72 \\
\text { hrs. }\end{array}$ & $\begin{array}{l}\text { F \& V } \\
\text { consumption, } \\
\text { anthropometry } \\
\text { and PA }\end{array}$ & $\begin{array}{l}\text { HPM and } \\
\text { SCT }\end{array}$ & $\begin{array}{l}\text { Researchers } \\
\text { and } \\
\text { researchers } \\
\text { trained } \\
\text { teachers. }\end{array}$ & $\begin{array}{l}\text { 24-hr DR, } \\
\text { anthropometr } \\
\text { y and PA } \\
\text { questionnaires } \\
\text { at PPI }\end{array}$ & $\begin{array}{l}\text { Intervention by TT } \\
\text { increase F\&V } \\
\text { consumption } \\
\text { among learners }\end{array}$ \\
\hline
\end{tabular}




\begin{tabular}{|c|c|c|c|c|c|c|c|c|c|}
\hline $\begin{array}{l}\text { Author, year } \\
\text { \& Country }\end{array}$ & $\begin{array}{l}\text { Participant } \\
\text { s }\end{array}$ & $\begin{array}{l}\text { Study } \\
\text { design }\end{array}$ & $\begin{array}{l}\text { Intervention } \\
\text { components }\end{array}$ & $\begin{array}{l}\text { Interv } \\
\text { ention } \\
\text { durati } \\
\text { on }\end{array}$ & Issues addressed & $\begin{array}{l}\text { Theory } \\
\text { based }\end{array}$ & $\begin{array}{l}\text { Intervention } \\
\text { implementer } \\
\mathrm{S}\end{array}$ & Evaluation & Outcomes \\
\hline $\begin{array}{l}\text { Spiegel and } \\
\text { Foulk, } 2006 \\
\text { (USA) }\end{array}$ & $\begin{array}{l}1013 \\
\text { learners in } \\
\text { grades } 4 \\
\text { and } 5 \text { from } \\
69 \text { classes }\end{array}$ & $\begin{array}{l}\text { Randomis } \\
\text { ed } \\
\text { controlled } \\
\text { trial }\end{array}$ & $\mathrm{NE}+\mathrm{PA}$ & $\begin{array}{l}8 \\
\text { month } \\
\text { s }\end{array}$ & $\begin{array}{l}\text { To increase F\&V } \\
\text { intake and PA }\end{array}$ & TRA & $\begin{array}{l}\text { Trained } \\
\text { teachers }\end{array}$ & $\begin{array}{l}\text { Anthropometr } \\
\mathrm{y}, \\
\text { questionnaires } \\
\text { at PPI }\end{array}$ & $\begin{array}{l}\text { Positive changes in } \\
\text { BMI, F\&V intake } \\
\text { and increase in PA }\end{array}$ \\
\hline
\end{tabular}

Notes: Abreviations: F\&V - fruits and vegetables, PA - physical activity, PE - physical education, HPM - health promotion model, SCT - social cognitive theory, 24-hr DR - 24-hour dietary recall, PPI - pre and post-intervention, SEM - social ecological model, KAP - knowledge attitudes and practices, SSW school staff wellness, SBI - school-based intervention, PB - planned behaviour, EM - ecological model, TRA - theory of reasoned action, FFVS - free fruits and vegetable supply. 
Therefore the intervention duration reported in weeks in this review represents the contact hours. The duration of intervention varied greatly from 4 weeks to $2 \frac{1}{2}$ years. Seven studies included follow-up measures to evaluate intervention effectiveness. The duration of followup varied from 3 weeks to 2 years. The intervention foci of the studies reviewed were diverse, and included increased fruit and vegetable intake (Story et al., 2002); overweight and obesity reduction (Jansen et al., 2008); increased physical activity (Nabipour et al., 2004); increased consumption of grains and legumes (Burgess-Champoux et al., 2008) and heart health nutrition (Francis et al., 2010). Other interventions focused on increased nutrition knowledge, attitudes, behaviour and self-efficacy (Subba Rao et al., 2006), and improved nutritional and health status (Shi-Chang et al., 2004).

\section{Definition of school-based nutrition education intervention}

None of the studies reviewed described the concept of their intervention in respect of schoolbased NE. However, many of the studies followed the principles of Contento's definition that "NE is any combination of educational strategies, accompanied by environmental supports, designed to facilitate voluntary adoption of food choices and other food- and nutrition-related behaviours conducive to health and well-being" (Contento, 2007). Hence, the components of educational strategies in the form of learning theories, and the use of schools and teachers as environmental support were present. The important role of teachers to implement interventions was evident in all the studies involving teachers. The remaining studies

followed the principles portrayed in the FAO's definition that $\mathrm{NE}$ is "that group of communication activities aimed at achieving a voluntary change in nutrition related behaviour to improve the nutritional status of the population" (FAO, 1997). 


\section{Study designs and intervention approaches}

The randomised control trial study design was used in 10 studies, group or cluster randomised control trials were used in 7 studies, while 7 studies used quasi-experimental designs. Other study designs used included the intervention mapping approach (Kafatos et al., 2004) and school-based randomised trial (Parker and Fox, 2001). Intervention approaches of studies were in 3 categories. These are those that involved classroom NE only, those that involved classroom NE with 1 or 2 nutrition-related services, and those that involved classroom NE with more than 2 nutrition-related services (multi-component).

\section{Features of nutrition education interventions}

\section{Implementation}

Intervention in 12 studies involved trained teachers who implemented interventions with learners, while 8 studies involved classroom teachers who were not reported to have received training to implement or assist in implementing interventions with learners. Other implementers of interventions in the articles reviewed were trained community educators, trained peer leaders, kitchen and garden specialist staff and researchers (Gibbs et al., 2013; Jones et al., 2011; Rosario et al., 2012).

\section{Behavioural theories}

Theories of behaviours have been used with various degrees of success to implement schoolbased intervention (Contento, 2007). The theories of behaviours such as the SCT, Social Marketing Theory, Stages of Change Theory, HPM, Health Belief Model and others characterised the implementation of successful interventions (Steyn et al., 2009). In the present review, intervention implementations in 8 studies were based on a combination of theories. These included the SCT and Theory of Planned Behaviour (PB) (Prelip et al., 2011; Prelip et al., 2012), the PB and Ecological Model (EM) (Jansen et al., 2008), the SCT and Social Ecological Model (SEM) (Lien et al., 2010), the SEM and the HPM (Gibbs et al., 
2013), the HPM and SCT (Rosario et al., 2012), the SEM and SCT (Draper et al., 2011) and the SCT and Self-determination theory (Lee at al., 2013). Thirteen studies based their interventions on one theory while 18 studies did not base their interventions on any theory or no theory was reported.

\section{Evaluation of interventions}

Most of the interventions resulted in favourable outcomes on some objectives and unfavourable outcomes on the other objectives. The results shown in the summaries of reviews (table 1) reported favourable or unfavourable outcomes on main objectives. Very few studies had all their objectives completely met by the interventions. In Panunzio and colleagues' intervention to address consumption of fruits and vegetables by using two different approaches, it was concluded that teacher intervention was superior to nutritionist intervention. There were significant improvements in fruit, vegetable and legume consumption, and a decline in the percentage of obesity among learners in teachers' intervention (Panunzio et al., 2007). Singhal et al. (2010) recorded favourable results on all objectives as there were statistically significant improvements in dietary behaviours, Body Mass Index (BMI) and biochemical profiles of learners. Eight studies reported unfavourable to modest results in their intervention outcomes. Unfavourable results included no change in dietary habits, no improvement in dietary intake pattern, no clear result reported, no significant changes in school-based eating, no significant increase in students' fruit and vegetable intake and no significant changes in BMI. The studies with the aim of reducing overweight and obesity did not achieve their objectives. (Fernandes et al., 2009; Jansen et al., 2008).

A growing body of knowledge in NE has shown inadequate evaluation procedures to assess effectiveness of interventions (Fahlman et al., 2008; Perez-Rodigo and Aranceta, 2001). Most NE interventions were aimed at implementation towards behavioural change. Only 7 studies 
included follow-up evaluation of intervention and follow-up evaluation varied from 3 weeks to 2 years. Intervention outcomes were favourable in all studies involving follow up, but were not sustainable in the first year and second year of follow-up. In Forneris et al. (2010)'s study, the improvement in nutrition knowledge and self-efficacy achieved at post-test was not sustainable in the first year and second year of follow up respectively.

\section{Facilitators of interventions}

Factors that contributed to success of interventions in this review included the use of trained teachers which led to increase in learners' nutrition knowledge, positive changes in BMI, increase in fruits and vegetables intake and improvement in educators' understanding of $\mathrm{NE}$ (Kafatos et al., 2004; Spiegel and Foulk, 2006, Lee et al., 2013). The use of theories of behaviours contributed to success of interventions as shown by a positive impact on learners' health, increased intake of whole-grain foods and reduced intake of fried foods (Breslin and Brennan 2012; Burgess-Champoux et al., 2007; Francis et al., 2010). Interventions with simple design helped learners to positively respond to diets offered at school (Jones et al., 2011).

\section{Challenges of interventions}

Difficulties observed in interventions in the studies reviewed included time constraints (ShiChang et al., 2004; Parker and Fox, 2001), training of teachers (Draper et al., 2010), multicomponent interventions (Preli et al., 2012; Francis et al., 2010) and school policies (Siega-Riz et al., 2011). 


\section{Discussion}

The purpose of this review was to assess published articles on school-based NE intervention with particular reference to teachers' involvement, in order to identify factors hindering or contributing to the effectiveness of interventions.

\section{Features of school-based NE interventions}

The use of behavioural theories such as the SCT, HPM, PB, SEM and implementers of intervention namely teachers, peer leaders, community educators, and researchers as revealed in this review have been reported in the literature (Contento, 2007). Intervention implementation in the classroom, on the playground and at the cafeteria was observed in the review. These involved delivery of classroom NE, physical activity, family involvement, label reading and cafeteria menu which are consistent with findings of Perez-Rodigo and Aranceta (2001). Simply designed, a teacher-oriented NE programme implemented even for a short duration can be very impactful, as this gives room for concerted efforts that produce great effect (Fernandes et al., 2009). Evaluation of intervention as revealed included the use of anthropometry, questionnaires, 24-hr record and lunchroom observation have been reported in previous studies (Perez-Rodigo and Aranceta, 2001; Steyn et al., 2009).

\section{Facilitators of school-based NE interventions}

\section{Training of teachers}

As observed from the studies, successful interventions were characterised by active involvement of trained teachers which resulted in realisation of project objectives (Francis et al,. 2010; Kafatos et al., 2004; Spiegel and Foulk, 2006). These results confirmed findings of a previous study (Shariff et al., 2008) that dietary behaviours of learners can be greatly influenced by classroom teachers who received training in NE. The study conducted by Panunzio et al. (2007) revealed that teacher intervention (dietary intervention implemented 
by trained teachers) was superior to nutritionist intervention (dietary education implemented by nutritionists to learners). Teachers who received training to implement nutrition education were better equipped to teach nutrition concepts to learners effectively. Teachers represent authority figures and role models to learners and for this reason can model healthy dietary behaviours (Rossiter et al.,2007). Moreover, teachers have the opportunity to integrate nutrition issues into other subjects thereby using a multi-faceted approach to emphasise nutrition messages (Panunzio et al., 2007). Thus an effectively implemented NE programme driven by trained teachers has the potential of self-sustainability, as teachers have the opportunity to continue on the established approach year in year out (Prelip et al., 2011). The fact that the majority of children are usually enrolled in schools where they have regular contacts with teachers (Rafiroiu \& Evans, 2005) is a strong point in NE intervention in schools.

\section{Behavioural theories}

Behavioural theories contributing to the success of interventions as revealed from the present review are diverse and are dictated by the design of the interventions. The combination of concepts of different theories can help to facilitate the realization of project goals. (Contento, 2007). This strategy has found useful applications in many successful interventions as demonstrated in many of the studies that used more than one theory in this review. The authors capitalised on strengths of the different theories to the advantage of their interventions (Rosario et al., 2012; Lee et al., 2013). However, the SCT was observed to have useful application in most of the interventions that were theory based. Out of the 22 studies that were theory based, the SCT was used in 12 studies. Most of the studies involving the SCT achieved their project objectives. The SCT has been widely used to design, implement and evaluate programmes and has been adjudged to help learners to increase knowledge, build skills and set behavioural goals (Glanz et al., 2002). Implementers of interventions 
often harness the strength of the SCT, in this way taking advantage of the impact of the school environment on learners' ability to learn new behaviours.

In addition, NE implemented by trained teachers has the prospect of achieving successes in other areas. Capacity to improve learners' academic performance (Shilts et al., 2009), to reduce some indices of ill-health such as risk of cardiovascular diseases and diabetes (Slawta and DeNeui, 2010) and to reduce percentage of obesity (Panunzio et al., 2007). Teacher oriented school-based NE intervention has the capacity to influence not only the learners', but also the teachers' nutritional well-being. In the Train the Trainer intervention, the trained implementers increased their nutrition knowledge and were able to convey nutrition knowledge to learners (Falter et al., 2011). Thus opportunities for teacher training are created that increased teachers' efficacy and confidence to teach nutrition effectively (Slawta and DeNeui, 2010; Spiegel and Foulk, 2006).

\section{Challenges of teacher oriented school-based NE}

Much as there are great prospects in teacher oriented school-based NE interventions they are not without challenges.

\section{Training challenges}

Training of teachers on the approach and content in order to get them equipped to teach nutrition effectively may not be a simple task. Prelip et al. (2011) expressed the concern of how teachers, who were already overwhelmed with academic matters, could be adequately trained to become nutrition educators. Teachers' individual approach, motivation and demeanour are factors that can dictate the delivery and the outcomes of interventions (Kafatos et al., 2004). Effective intervention would therefore require efforts to ensure teachers are well trained, motivated and implementation adequately monitored (Shariff et al., 2008). 


\section{Time constraints}

Teachers' work time is divided among several other school activities, aside teaching roles. As a result, interventions that did not have teachers' input and required a considerable amount of execution time might not receive teachers' adequate cooperation (Gross and Braun, 2010). Time constraints in respect of teacher training and implementation were expressed as common challenge in teacher oriented school-based NE interventions (Oldewage-Theron \& Egal, 2012; Steyn et al., 2009).

Establishment of nutrition as a subject in the school curriculum remains a challenge; instead, limited periods are often allotted to nutrition topics in other subjects (Shi-Chang et al., 2004; Unicef, 2009). This can result in limited nutrition information that can hardly be effectively communicated to learners by teachers.

\section{Interventions with multi-components activities}

School-based NE studies involving multi-component activities are often faced with challenges which can affect intervention outcomes. Challenges experienced included noncommitment from staff, (Parker \& Fox, 2001) complexities of monitoring and implementation in the presence of scarce resources, (Prelip et al., 2012) environmental context, (Francis et al., 2010) efficacy and feasibility challenges (Siega-Riz et al., 2011). Multi-component interventions usually take a considerable amount of classroom time, are labour intensive and may lack implementation fidelity (Reinaerts et al., 2008). Sustainability of favourable outcomes of NE interventions is a challenge (Kafatos et al., 2004). A heavily loaded intervention may lead to limited cooperation of teachers as was reported in the Healthkick Programme (Draper et al., 2010). In that study, implementation of the intervention as was originally planned had to be revised because of the unwillingness of the teachers to commit to the action plans. 


\section{Schools'policies}

The policies of the schools' authorities have rules and regulations guiding the conduct of research in schools (Parmer et al., 2009). Changes in schools' policies also do occur from time to time (Siega-Riz et al., 2011). These often limit the design and implementation of NE intervention that may be undertaken in schools.

\section{Implication for research}

The important influence of teachers in modifying learners' nutrition behaviours has been confirmed. Two groups of researchers (Rafiroiu \& Evans, 2005; Rossiter et al., 2007) brought out the need for teachers to model good nutrition behaviours to learners. Harnessing the strength of teachers to improve learners' dietary behaviours can significantly reduce children at risk of morbidity from obesity and other malnutrition diseases. As a means to strengthen teachers' influence on learners' behaviours, provision of necessary training in nutrition for teachers and making intervention implementation teacher friendly can be a viable strategy. In addition, if success of a school's NE is to be fully realized, planning of intervention with due consideration to school's policy, teachers' time and the use of theories of behaviour is recommended.

\section{Conclusions}

While this review has provided valuable insights, it has some limitations. It focused on the results of main objectives of interventions, whereas, interventions could have recorded many other successes/failures on other objectives which are not reported. The selection of articles using only 3 databases and Google search is characteristic of selection of studies in traditional literature review, which made this review prone to selection bias.

This review revealed the fact that appropriately motivated and adequately trained teachers are invaluable assets in interventions to improve the nutrition behaviours of learners. Not only 
are learners' nutrition knowledge impacted, but also the teachers' nutrition behaviours. In addition, teachers are able to sustain the system once established. The use of appropriate learning theories has also contributed to successes of interventions. Challenges associated with teacher oriented school-based NE interventions appeared to be training challenges, time constraints, sustainability of positive outcomes, multi-components activities and school policies. These may be overcome by properly designed and implemented interventions. The role of teachers is clearly central in nutrition education and changing food choices in schoolbased nutrition interventions (Panunzio et al., 2007). This factor needs to be fully explored in order to bring about sustainable and healthy dietary changes among learners. Understanding the issues that surround the roles of teachers can inform the effective planning and implementation of NE in schools.

\section{References}

Bergen, D. (1993), “Authentic performance assessment”, Child Educ., Vol. 70, pp. 99-101.

Blom-Hoffman, J., Kelleher, C., Power, T.J., and Leff, S.S. (2004), "Promoting healthy food consumption among young children: Evaluation of a multi-component nutrition education program”, J. Sch. Psychol., Vol. 42 No. 1, pp. 45-60.

Breslin, G. and Brennan, D. (2012), “A healthy lifestyle intervention delivered by aspiring physical education teachers to children from social disadvantage: study protocol and preliminary findings", Child Care in Practice, Vol. 18 No. 3, pp. 207-225.

Burgess-Champoux, T.L., Chan, H.W., Rosen, R., Marquart, L., and Reicks, M. (2008), "Healthy whole-grain choices for children and parents: a multi-component school-based pilot intervention", Public Health Nutr., Vol. 11 No. 8, pp. 849-859.

Cason, K.I. and Logan, B.N. (2006), "Educational intervention improves 4th grade school children's nutrition and physical activity knowledge and behaviours", Tropics Clin. Nutr., Vol. 21 No. 3, pp. 234-240. 
Connell, D.B., Turner, R.R. and Manson, E.F. (1985), "Summary findings of the school health education evaluation: health promotion effectiveness, implementation and cost", $J$. Sch. Health, Vol. 55, pp316-321.

Contento, I.R. (2007), Nutrition education linking research, theory and practice, Jones and Bartlett, Sudbury, MA.

Contento, I.R. (2008), "Nutrition education: linking research, theory, and practice", Asia Pacific J. Clin. Nutr., Vol. 17 Supp. 1, pp. 176-179.

De Onis, M., Blössner, M. and Borghi, E. (2010), "Global prevalence and trends of overweight and obesity among preschool children", Am. J. Clin. Nutr., Vol. 92 No. 5, pp. $1257-1264$.

Drake, L., Maier, C., Jukes, M., Patrikios, A. and Bundy, D. (2002), "School-age children: their nutrition and health", Standing Committee on Nutrition, Vol. 25, pp.4-30.

Draper, C., de Villiers, A., Lambert, E., Fourie, J., Hill, J., Dalais, L. and Steyn, N. (2010), "HealthKick: a nutrition and physical activity intervention for primary schools in low-income settings", BMC Public Health, Vol. 10, pp. 398, Available at: http://www.ncbi.nlm.nih.gov (accessed 12 July 2012).

Fahlman, M.M., Dake, J.A., McCaughtry, N. and Martin, J. (2008), “A Pilot Study to examine the effects of a nutrition intervention on nutrition knowledge, behaviors, and efficacy expectations in middle school children”, J. Sch. Health, Vol. 78, pp. 216-222.

Falter, R.A., Pignotti-Dumas, K., Popish, S.J., Petrelli, H.M., Best, M.A. and Wilkinson, J.J. (2011), "A service learning program in providing nutrition education to children", Am. J. Pharm. Educ., Vol. 75, pp. 85, Available at: http://dx.doi.org/10.5688/ajpe75585 (accessed 25 July 2012).

Fernandes, P.S., Bernardo Cde, O., Campos, R.M. and Vasconcelos, F.A. (2009), "Evaluating the effect of nutritional education on the prevalence of overweight/obesity and on foods eaten at primary schools", J. Pediatr., (Rio J), Vol. 85, pp. 315-321. 
FAO (1997), Past experiences and needs for nutrition education: Summary and conclusions of nine case studies, Nutrition Education for the Public, Available at: http://www.fao.org/docrep/W3733E/w3733e01 (accessed 8 April 2013).

FAO (2005), Nutrition education for the public: A framework for nutrition education

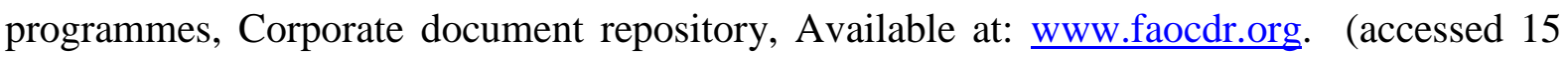
May 2012).

Fornari, A. (2006), "Developing an ethics curriculum using learner centred pedagogy", Internet J. Allied Health Sci. Prac., Available at: http://ijahsp.nova.edu (accessed 30 July 2012).

Forneris, T., Fries, E., Meyer, A., Buzzard, M., Uguy, S., Ramakrishnan, R. and Danish, S. (2010), "Results of a rural school-based peer-led intervention for youth: Goals for health", $J$. Sch. Health, Vol. 80 No. 2, pp. 57-65.

Francis, M., Nichols, S.S. and Dalrymple, N. (2010), "The effects of a school-based intervention programme on dietary intakes and physical activity among primary-school children in Trinidad and Tobago, Public Health Nutr., Vol. 13 No. 5, pp. 738-747.

Gibbs, L., Staiger, P.K., Johnson, B., Block, K., Macfarlane, S., Gold, L., Kulas, J., Townsend, M., Long, C. and Ukoumunne. (2013), “Expanding children's food experiences: the impact of a school-based kitchen garden program", J. Nutr. Educ. Behav., Vol. 45 No. 2, pp. 137-146.

Glanz, K., Rimer, B.K. and Lewis, F.M. (2002), Health behaviour and health education. Theory research and practice, Willey and Sons, San Francisco.

Gross, S.M., Pollock, E.D. and Braun, B. (2010), "Family influence: key to fruit and vegetable consumption among fourth- and fifth-grade students, J. Nutr. Educ. Behav., Vol. 42 No. 4, pp. 235-241.

He, M., Beynon, C., Sangster Bouck, M., St Onge, R., Stewart, S., Khoshaba, L. and Chircoski, B. (2009), "Impact evaluation of the northern fruit and vegetable pilot programme - a cluster-randomised controlled trial", Public Health Nutr., Vol. 12 No. 11, pp. 2199-2208. 
Hildebrand, D.A., Jacob, T. and Garrard-Foster, D. (2012), "Food and fun for everyone: A community nutrition education program for third- and fourth-Grade students suitable for school wellness programs. J. Nutr. Educ. Behav., Vol. 44 No. 1, pp. 93-95.

Hoelscher, D.M., Feldman, H.A., Johnson, C.C., Lytle, L.A., Osganian, S.K., Parcel, G. S. and Nader, P. R. (2004), "School-based health education programs can be maintained over time: results from the CATCH Institutionalization study", Prev. Med., Vol. 38 No. 5, pp. 594606.

Holli, B.B., Calabrese, R.J. and Maillet, J.O. (2003), Communication and education skills for dietetics proffessionals (4th ed), Lippincott Williams \& Wilkins, Baltimore, MD.

Jansen, W., Raat, H., Zwanenburg, E., Reuvers, I., van Walsem, R. and Brug, J. (2008), “A school-based intervention to reduce overweight and inactivity in children aged 6-12 years: study design of a randomized controlled trial”, BMC Public Health., Vol. 8 No. 1, pp. 257.

Jones, S., Spence, M., Hardin, S. and Clemente, N.A. (2011), "Youth Can! results of a pilot trial to improve the school food environment", J. Nutr. Educ. Behav., Vol. 43 No. 4, pp. 284287.

Kabahenda, M., Mullis, R.M., Erhardf, J.G., Nurlhrup-Clewes, C. and Nichols, S.Y. (2011), "Nutrition education to improve dietary intake and micronutrient nutriture among children in less-resourced areas: a randomised controlled intervention in Kabarole district, Western Uganda", S. Afr. J. Clin. Nutr., Vol. 24 No. 2, pp. 82-88.

Kafatos, I., Peponaras, A., Linardakis, M. and Kafatos, A. (2004), "Nutrition education and Mediterranean diet: exploring the teaching process of a school-based nutrition and media education project in Cretan primary schools", Public Health Nutr., Vol. 7 No. 7, pp. 969-975.

Katz, D.L., Katz, C.S., Treu, J.A., Reynolds, J., Njike, V., Walker, J. and Michael, J. (2011), "Teaching healthful food choices to elementary school students and their parents: The nutrition Detectives TM program", J. Sch. Health, Vol. 81 No. 1, pp. 21-28.

Lakshman, R., Sharp, S., Ong, K. and Forouhi, N. (2010), “A novel school-based intervention to improve nutrition knowledge in children: cluster randomised controlled trial", BMC Public Health, Vol. 10 No. 1, pp. 123-132. 
Lee, H., Contento, I.R. and Koch, P. (2013), "Using a systematic conceptual model for a process evaluation of a middle school obesity risk-reduction nutrition curriculum intervention: choice, control and Change”. J. Nutr. Educ. Behav., Vol. 45 No. 2, pp. 126-136.

Lien, N., Bjelland, M., Bergh, I.H., Grydeland, M., Anderssen, S.A., Ommundsen, Y. and Klepp, K.I. (2010), "Design of a 20-month comprehensive, multicomponent school-based randomised trial to promote healthy weight development among 11-13 year olds: The health in adolescents study", Scandinavian J. Public Health, Vol. 38 Suppl. 5, pp. 38-51.

Nabipour, I., Imami, S.R., Mohammadi, M.M., Heidari, G., Bahramian, F., Azizi, F. and Klepp, K.I. (2004), “A school-based intervention to teach 3-4 grades children about healthy heart; the Persian Gulf healthy heart project", Indian J. Med. Sci., Vol. 58 No. 7, pp. 289-296.

Oldewage-Theron, W. and Egal, A. (2012), "Impact of nutrition education on nutrition knowledge of public school educators in South Africa: A pilot study", Health SA Gesondheid, Vol. 17 No. 1, pp. 602-609.

Panunzio, M.F., Antoniciello, A., Allessandra, P. and Dalton, S. (2007), "Nutrition education intervention by teachers may promote fruit and vegetable consumption in Italian students", Nutrition Research, Vol. 27 No. 9, pp. 524-528.

Parker, L. and Fox, A. (2001), The Peterborough schools nutrition project: a multiple intervention programme to improve school-based eating in secondary schools. Public Health Nutr., Vol. 4 No. 6, pp. 1221-1228.

Parmer, S.M., Salisbury-Glennon, J., Shannon, D. and Struempler, B. (2009), "School gardens: an experiential learning approach for a nutrition education program to increase fruit and vegetable knowledge, preference, and consumption among second-grade students", $J$. Nutr. Educ. Behav., Vol. 41 No. 3, pp. 212-227.

Perez-Rodigo, C. and Aranceta, J. (2001), "School based nutrition education: lessons learned and new perspectives", Public Health Nutr., Vol. 4 No. 1A, pp. 131-139.

Prelip, M., Kinsler, J., Chan, L.T., Erausquin, J T. and Slusser, W. (2012), "Evaluation of a school-based multicomponent nutrition education program to improve young children's fruit and vegetable consumption", J. Nutr. Educ. Behav., Vol. 44 No. 4, pp. 310-318. 
Prelip, M., Slusser, W., Thai, C.L., Kinsler, J. and Erausquin, J.T. (2011), "Effects of a school-based nutrition program diffused throughout a large urban community on attitudes, beliefs, and behaviors related to fruit and vegetable consumption", J. Sch. Health., Vol. 81 No. 9 , pp. 520-529.

Rafiroiu, A.C. and Evans, A. (2005), "Nutrition knowledge, attitudes and practices among nutrition educators in the South", Am. J. Health Studies, Vol. 20, pp. 29-38.

Reinaerts, E., Crutzen, R., Candel, M., De Vries, N.K. and De Nooijer, J. (2008), “Increasing fruit and vegetable intake among children: comparing long-term effects of a free distribution and a multicomponent program", Health Educ. Res., Vol. 23 No. 6, pp. 987-996.

Rosario, R., Araujo, A., Oliveira, R., Padrao, P., Lpoes, O., Teixeira, V. and Moreira, P. (2012), "The impact of an intervention taught by trained teachers on childhood fruit and vegetable intake: A randomized trial", $J$. Obesity, Available at: http://www.ncbi.nlm.nih.gov/pubmed/22523664 (accessed 25October 2012).

Rossiter, M., Glanville, T., Taylor, J. and Blum, I. (2007), "School food practices of prospective teachers", J. Sch. Health, Vol. 77 No. 10, pp. 694-700.

Shariff, Z.M., Bukhari, S.S., Othman, N., Hashim, N., Ismail, M., Jamil, Z. and Hussein, Z. A. M. (2008), "Nutrition education intervention improves nutrition knowledge, attitude and practices of primary school children: a pilot study", Int. Electronic J. Health. Educ., Vol. 11, pp. 119-132.

Shi-Chang, X., Xin-Wei, Z., Shui-Yang, X., Shu-Ming, T., Sen-Hai, Y., Aldinger, C. and Glasauer, P. (2004), "Creating health-promoting schools in China with a focus on nutrition" Health Promot. Int., Vol. 19 No. 4, pp. 409-418.

Shilts, M. K., Lamp, C., Horowitz, M. and Townsend, M. S. (2009), "Pilot study: Eat-fit impacts sixth graders' academic performance on achievement of Mathematics and English education standards", J. Nutr. Educ Behav., Vol. 41 No. 2, pp. 127-131.

Siega-Riz, A., El Ghormli, L., Mobley, C., Gillis, B., Stadler, D. and Hartstein, J. (2011)”, The effects of the healthy study intervention on middle school student dietary intakes. Int. J. Behav. Nutr. Phys. Act., Vol. 8 No. 1, pp. 7. 
Singhal, N., Misra, A., Shah, P. and Gulati, S. (2010), "Effects of controlled school-based multi-component model of nutrition and lifestyle interventions on behaviour modification, anthropometry and metabolic risk profile of urban Asian Indian adolescents in North India”. Eur. J. Clin. Nutr., Vol. 64 No. 4, pp. 354-364.

Slawta, J.N. and DeNeui, D. (2010), Be a fit kid: Nutrition and physical activity for the fourth grade. Health Promot. Pract., Vol. 11 No. 4, pp. 522-529.

Spiegel, S.A. and Foulk, D. (2006), "Reducing overweight through a multidisciplinary school-based intervention", Obesity, Vol. 14 No. 1, pp. 88-96.

Stevens, G.A., Singh, G.M., Lu, Y., Danaei, G., Lin, K.J., Finucane, M.M., Bahalim, A.N., Russell K McIntire, R.K., Gutierrez, H.R., Cowan, M., Paciorek, C.J., Farzadfar, F., Riley, L., Ezzati, M. (2012), "National, regional, and global trends in adult overweight and obesity prevalence", Popul. Health Metr., Available at: http://www.pophealthmetrics.com/content/10/1/22 (accessed 25 March 2012).

Steyn, N.P., Lambert, E.V., Parker, W., McHiza, Z. and De Villiers, A. (2009), “A review of school nutrition interventions globally as an evidence base for the development of the healthkick programme in the Western Cape, South Africa", S. Afr. J. Clin. Nutr., Vol. 22 No. 3, pp. 145-152.

Story, M., Lytle, L.A., Birnbaum, A.S. and Perry, C.L. (2002), "Peer-led, school-based nutrition education for young adolescents: feasibility and process evaluation of the TEENS study", J. Sch. Health, Vol. 72 No. 3, pp. 121-127.

Subba Rao, G.M., Rao, D.R., Venkaiah, K., Dube, A.K. and Sarma, K.V. (2006), "Evaluation of the Food and Agriculture Organization's global school-based nutrition education initiative, Feeding Minds, Fighting Hunger (FMFH), in schools of Hyderabad, India Public Health Nutr., Vol. 9 No. 8, pp. 991-995.

Swindle, S., Baker, S.S. and Auld, G.W. (2007), "Operation frontline: Assessment of longerterm curriculum effectiveness, evaluation strategies, and follow-up methods", J. Nutr. Educ. Behav., Vol. 39 No.4, pp. 205-213.

UN Millennium Project (2005), UN investing in development: A practical plan to achieve the millennium development goals, Communications Development Inc, Washington, DC. 
Unicef (2009), Tracking progress of child and maternal nutrition - a survival and development priority, UNICEF, New York.

Van Cauwenberghe, E., Maes, L., Spittaels, H., van Lenthe, F.J., Brug, J., Oppert, J.M. and De Bourdeaudhuij, I. (2010), "Effectiveness of school-based interventions in Europe to promote healthy nutrition in children and adolescents: systematic review of published and 'grey' literature. Br. J. Nutr., Vol. 103 No. 6, pp. 781-797.

Walsh, C.M., Dannhauser, A. and Joubert, G. (2003), "Impact of a nutrition education programme on nutrition knowledge and dietary practices of lower socioeconomic communities in the Free state and Northern Cape", S. Afr. J. Clin. Nutr., Vol. 16 No. 3, pp. $89-95$.

WHO (2006), Repositioning Nutrition as central to development: A strategy for large scale action. World Bank, Washington, DC.

WHO (2013). Mortality and global world estimates, Available at:

http://www.who.int/research/en/index.html. (accessed 10 December 2012). 